\title{
Interaction Effect of Phosphorus and Sulphur on Yield and Quality of Soybean in a Vertisol
}

\author{
Jarupula Suman*, B.S. Dwivedi, A.K. Dwivedi and S.K. Pandey \\ College of Agriculture, JNKVV, Jabalpur-482 004 (MP), India \\ *Corresponding author
}

\section{A B S T R A C T}

\begin{tabular}{|l|}
\hline Ke y w o r d s \\
$\begin{array}{l}\text { Synergistic } \\
\text { relationship, Protein } \\
\text { and oil content }\end{array}$ \\
\hline Article Info \\
\hline $\begin{array}{l}\text { Accepted: } \\
\text { 04 February } 2018 \\
\text { Available Online: } \\
\text { 10 March } 2018\end{array}$ \\
\hline
\end{tabular}

Keywords

Synergistic relationship, Protein and oil content

\section{Introduction}

Soybean is a well-known oilseed as well as pulses crop which is grown in various countries. Soybean, besides having excellent nutritional quality, contributes the highest to world oil production. Through, there has been a prodigious increase in the acreage (1.5 to 6.3 $\mathrm{m}$ ha) as well as production (1.0 to $6.1 \mathrm{mt}$ ) of soybean during last one and half decade, even then. The share of India in world soybean production is significantly (nearly 3.8\%) attributed to low productivity (SOPA, 2015). Phosphorus, an important constituent of biochemical products in plant itself plays a key role in balance nutrition of the crop and affects productivity of soybean. Next most important emerging nutrient that is showing wide spread deficiency is sulphur. Sulphur is essential for synthesis of proteins, vitamins and sulphur containing essential amino acids and is also associated with nitrogen metabolism. The good yield of soybean can be achieved by balanced and adequate supply of phosphate, sulphur and other deficient, nutrients.

Sulphur interacts with phosphorus as phosphate ion is more strongly bound than sulphate (Choudhary and Das, 1996; Aulakh et al., 1990). Phosphorus fertilizer application results increased of anion adsorption sites by phosphate, which releases sulphate ions into the soil solution (Chandra Deo and Khaldelwal, 2009). Thus, it may be subjected 
to leaching if not taken up by plant roots. Studies have indicated both synergistic and antagonistic relationship between sulphur and phosphorus but their relationship depends on their rate of application and crop species (Chaurasia et al., 2009; Dwivedi and Bapat, 1998). Synergistic effect of applied $P$ and $S$ was observed by (Kumawat et al., 2004), (Kumar and Singh, 1980) for soybean, (Islam et al., 2006) for rice, (Pandey et al., 2003) for linseed, (Chandra Deo and Khaldelwal, 2009) for chickpea.

Antagonistic relationship between $\mathrm{P}$ and $\mathrm{S}$ was observed in moong and wheat by (Islam et al., 2006) and in lentil and chickpea by Hedge and Murthy (Aulakh et al., 1990). The interaction of these nutrient elements may affect the critical levels of available $\mathrm{P}$ and $\mathrm{S}$ below which response to their application could be observed. Information on effect of combined application of $\mathrm{P}$ and $\mathrm{S}$ on yield, quality and content of each nutrient in soybean is rather limited. Therefore, the present investigation was undertaken to study interactive effects of $\mathrm{P}$ and $\mathrm{S}$ application on yield and quality of soybean.

\section{Materials and Methods}

The study was conducted in the All India Coordinated Research Project on Long Term Fertilizer Experiment (LTFE), Jawaharlal Nehru Krishi Vishwa Vidyalaya, Jabalpur, Madhya Pradesh. The experimental sites (2310" N latitude and 79 57" E longitude) have a semi-arid and sub-tropical climate with a characteristic feature of dry summer and cold winter.

In winter season i.e. from November to February the temperature ranges from $8.9^{\circ} \mathrm{C}$ to $34.5^{\circ} \mathrm{C}$ and the relative humidity varies from $70 \%$ to $90 \%$. Dry and warm weather usually persists during the month of March to June. The temperature may rise as high as $46^{\circ} \mathrm{C}$ during these summer months. Monsoon season extends from mid-June to mid-September. The temperature during this period varies between $22^{\circ} \mathrm{C}$ and $38^{\circ} \mathrm{C}$ and the relative humidity ranges from 70 to $80 \%$. The total annual rainfall varies from 1200 to $1500 \mathrm{~mm}$. The soil of the experimental sites falls under Vertisol and belongs to Kheri-series of fine montmorillonite, Hyperthermic family of Typic Haplusterts popularly known as "medium black soil". At the inception of this experiment in 1972, pooled soil sample were drawn from the surface layers $(0-20 \mathrm{~cm})$ of the experimental field has $\mathrm{pH}$ (7.6), electrical conductivity (0.18), organic carbon (0.57\%), available $\mathrm{N}(193.0 \mathrm{~kg}$ ha-1) available $\mathrm{P}(7.60$ $\mathrm{kg}$ ha-1) and available $\mathrm{K}(370 \mathrm{~kg}$ ha-1) and available sulphur (17.47 $\mathrm{kg}$ ha-1). The treatments consist of T1-50\% NPK, T2-100\% NPK, T3-150\% NPK, T4-100\% NP, T5-100\% N, T6-100\% NPK + FYM, T7-100\% NPK-S and $\mathrm{T} 8$-Control, and replicate with four times in randomized block design.

\section{Experimental details}

Design used: Randomized block design

Replication: 04

Treatments: 8

Plot size: $17 \times 10.8 \mathrm{~m}\left(183.6 \mathrm{~m}^{2}\right)$

Space between replications: $2 \mathrm{~m}$

Space between plots: $1 \mathrm{~m}$

Experimental area: 146X58 m

Cropping sequence: Soybean-wheat

\section{Results and Discussion}

\section{Grain and straw yield}

With increasing level (Table 3) of both phosphorus and sulphur grain and straw yield of soybean were increased significantly. The percent increase in grain yield due to phosphorus and sulphur varied from 12.31 to $20.8 \%$ and 6.9 to $12.1 \%$, respectively, whereas the straw yield was increased from 10.6 to 
$15.9 \%$ and 6.3 to $12.9 \%$. The magnitude of response was more in case of phosphorus as compared to sulphur. Synergistic effect of phosphorus and sulphur interaction on grain and straw yield was highest at $80 \mathrm{~kg} \mathrm{P}_{2} \mathrm{O}_{5}$ and $20 \mathrm{~kg} \mathrm{~S} \mathrm{ha}{ }^{-1}$. The magnitude of increase in grain and straw yield was 12.4 and $16.2 \%$ due to combined application of phosphorus and sulphur $80 \mathrm{~kg}$ P2O5 and $20 \mathrm{~kg} \mathrm{~S} \mathrm{ha}^{-1}$ over control, respectively. The synergistic effect of $\mathrm{P}$ and $\mathrm{S}$ may be due to utilization of high quantities of nutrients through their welldeveloped root system and nodules which might have resulted in better growth and yield at soil.

These results confirm the earlier findings of (Nagar et al., 1993) in soybean, (Sinha et al., 1995) in winter maize, (Choudhary and Das, 1996) in black gram, (Shankaralingappa et al., 1999) in cowpea, (Randhawa and Arora, 2000) in wheat, (Teotia et al., 2000) in moong bean, (Kumawat et al., 2004) in taramira and (Islam et al., 2006) in rice. (Kumar and Singh, 1980) with soybean reported a suitable balance between $\mathrm{P}$ and $\mathrm{S}$ for producing increased yield. (Aulakh et al., 1990) and (Singh et al., 1995) have shown that nature of $\mathrm{P}$ and $\mathrm{S}$ interaction depends on their rates of application.

\section{Nitrogen and protein content}

Nitrogen content (Table 2) was significantly increased with the increase in level of $\mathrm{P}$ and $\mathrm{S}$. (Dwivedi and Bapat, 1998) reported that nitrogen content in soybean increased significantly by $\mathrm{P}$ and $\mathrm{S}$ application up to 50 $\mathrm{kg} \mathrm{ha}^{-1}$ of each nutrient. The interaction of $\mathrm{P}$ and $\mathrm{S}$ was significant and maximum nitrogen content was recorded at $80 \mathrm{~kg} \mathrm{P}_{2} \mathrm{O}_{5}$ and $20 \mathrm{~kg}$ $\mathrm{S} \mathrm{ha}{ }^{-1}$.Protein content in soybean grain was increased significantly with application of $\mathrm{P}$ and $\mathrm{S}$ individually as well as in combination (Table 2). The maximum increase in protein content $(43.20 \%)$ was obtained with $40 \mathrm{~kg}$
$\mathrm{P}_{2} \mathrm{O}_{5}$ and $20 \mathrm{~kg} \mathrm{~S} \mathrm{ha}{ }^{-1}$ together. Protein was increased by $53.29 \%$ over control. The response to applied $\mathrm{P}$ with respect to protein content in soybean is attributed to more nitrogen fixation. Similar results were also reported by (Shankaralingappa et al., 1999) in cowpea and (Kumawat et al., 2004) in taramira.

Increasing doses of sulphur application resulted in a significant increase in protein content of soybean. The positive response to added sulphur is assigned to low status of available $S$ of soil or due to stimulating effect of applied sulphur in the synthesis of chloroplast protein resulting in greater photosynthetic efficiency which in turn translated in term of increased yield. (Dwivedi and Bapat, 1998) reported significant increase in the protein content of soybean with application of $\mathrm{P}$ and $\mathrm{S}$ up to $50 \mathrm{~kg} \mathrm{ha}^{-1}$ over control. The findings are similar to (JogendraSingh et al., 1997) in summer moong and (Srinivasan et al., 2000) in black gram.

\section{Phosphorus and sulphur content}

With increasing in level of S from 0 to 40 and 40 to $80 \mathrm{~kg} \mathrm{ha}^{-1}, \mathrm{P}$ and $\mathrm{S}$ content in grain and straw were increased significantly. Similarly P and $\mathrm{S}$ contents were increased significantly with increasing levels of phosphorus from 0 to 10 and 10 to $20 \mathrm{~kg} \mathrm{P}_{2} \mathrm{O}_{5} \mathrm{ha}^{-1}$. The combined application of $40 \mathrm{~kg} \mathrm{P}_{2} \mathrm{O}_{5}$ and $20 \mathrm{~kg} \mathrm{~S}^{-1}$ significantly increased $\mathrm{P}$ and $\mathrm{S}$ content in grain and straw (Table 2).

Phosphorus content in soybean ranged from 0.23 to $0.37 \%$ in grain and 0.12 to $0.26 \%$ in straw, while $\mathrm{S}$ content ranged from 0.30 to $0.40 \%$ in grain and 0.10 to $0.13 \%$ in straw. Similar results were reported by (Teotia et al., 2000) and (Islam et al., 2006) in mungbean, (Singh and Singh) in black gram and (Chandra Deo and Khaldelwal, 2009) in chickpea. 


\section{Nutrient sources}

\begin{tabular}{|l|l|l|}
\hline i. & Nitrogen & Urea $(46 \% \mathrm{~N})$ \\
\hline ii. & Phosphorus & $\begin{array}{l}\text { Single superphosphate }\left(16 \% \mathrm{P}_{2} \mathrm{O}_{5}\right) \\
\left(46 \% \mathrm{P}_{2} \mathrm{O}_{5}\right) \text { in } \mathrm{T}_{7}\end{array}$ \\
\hline iii. & Potassium & Muriate of potash $\left(60 \% \mathrm{~K}_{2} \mathrm{O}\right)$
\end{tabular}

Table.1 Physico-chemical properties of soil (0-20 cm depth) at the start of the LongTerm Fertilizer Experiment (1972)

\begin{tabular}{|c|c|c|c|}
\hline S. No. & $\begin{array}{r}\text { Soil Properties } \\
\end{array}$ & Unit & Value \\
\hline \multirow[t]{4}{*}{1.} & Mechanical composition & & \\
\hline & i. $\quad$ Sand & $\%$ & 25.27 \\
\hline & ii. & $\%$ & 17.91 \\
\hline & iii. Clay & $\%$ & 56.82 \\
\hline 2 & Textural class & - & Clay \\
\hline 3. & Bulk density & $\mathrm{Mg} \mathrm{m}^{-3}$ & 1.3 \\
\hline 4. & Particle density & $\mathrm{Mg} \mathrm{m}^{-3}$ & 2.5 \\
\hline 5. & Cation exchange capacity & $\mathrm{C}$ mol $\left(\mathrm{P}^{+}\right) \mathrm{kg}^{-1}$ & 49.0 \\
\hline 6. & $\mathrm{pH}(1: 2.5)$ & -- & 7.6 \\
\hline 7. & Electrical conductivity $(1: 2.5)$ & $\mathrm{dSm}^{-1}$ & 0.18 \\
\hline 8. & Organic carbon & $\mathrm{g} \mathrm{kg}^{-1}$ & 5.70 \\
\hline 9. & Calcium carbonate & $\%$ & 4.60 \\
\hline 10. & Available nitrogen & $\mathrm{kg} \mathrm{ha}^{-1}$ & 193.0 \\
\hline 11. & Available phosphorus & $\mathrm{kg} \mathrm{ha}^{-1}$ & 7.60 \\
\hline 12. & Available potassium & $\mathrm{kg} \mathrm{ha}^{-1}$ & 370.0 \\
\hline 13. & Available sulphur & $\mathrm{kg} \mathrm{ha}^{-1}$ & 17.47 \\
\hline 14. & Available zinc & $\mathrm{mg} \mathrm{kg}^{-1}$ & 0.33 \\
\hline
\end{tabular}

Source: Annual report (2014) of AICRP on Long-Term Fertilizer Experiment, JNKVV, Jabalpur.

Table.2 Effect of continuous addition of fertilizers and manure on distribution of available nutrients

\begin{tabular}{|c|c|c|c|c|c|c|c|c|}
\hline \multirow{3}{*}{ Treatments } & \multicolumn{8}{|c|}{ A vailable nutrients status } \\
\hline & \multicolumn{2}{|c|}{$\mathrm{N}\left(\mathrm{kg} \mathrm{ha}^{-1}\right)$} & \multicolumn{2}{|c|}{$\mathrm{P}\left(\mathrm{kg} \mathrm{ha}^{-1}\right)$} & \multicolumn{2}{|c|}{$\mathrm{K}\left(\mathrm{kg} \mathrm{ha}^{-1}\right)$} & \multicolumn{2}{|c|}{$\mathrm{S}\left(\mathrm{kg} \mathrm{ha}^{-1}\right)$} \\
\hline & $\begin{array}{c}0-15 \\
\mathrm{~cm}\end{array}$ & $\begin{array}{c}15-30 \\
\mathrm{~cm}\end{array}$ & $\begin{array}{c}0-15 \\
\mathrm{~cm}\end{array}$ & $\begin{array}{c}15-30 \\
\mathrm{~cm}\end{array}$ & $\begin{array}{c}0-15 \\
\mathrm{~cm}\end{array}$ & $\begin{array}{c}15-30 \\
\mathrm{~cm}\end{array}$ & $\begin{array}{c}0-15 \\
\mathrm{~cm}\end{array}$ & $\begin{array}{c}15-30 \\
\mathrm{~cm}\end{array}$ \\
\hline $50 \%$ NPK & 217.00 & 182.00 & 22.61 & 20.16 & 243 & 234 & 24.17 & 22.34 \\
\hline $100 \%$ NPK & 275.00 & 238.00 & 33.18 & 28.95 & 275 & 253 & 34.98 & 32.64 \\
\hline $150 \%$ NPK & 291.00 & 260.00 & 40.55 & 39.15 & 296 & 275 & 39.30 & 37.21 \\
\hline $100 \% \mathrm{NP}$ & 240.00 & 215.00 & 30.75 & 28.88 & 225 & 180 & 30.82 & 27.40 \\
\hline $100 \% \mathrm{~N}$ & 198.00 & 180.00 & 11.26 & 10.80 & 207 & 172 & 15.08 & 14.63 \\
\hline $100 \%$ NPK + FYM & 310.00 & 280.00 & 42.88 & 40.81 & 328 & 297 & 42.66 & 38.47 \\
\hline $100 \%$ NPK (S FREE) & 248.00 & 217.00 & 30.15 & 27.86 & 255 & 245 & 15.94 & 14.63 \\
\hline CONTROL & 182.00 & 165.00 & 10.01 & 9.80 & 208 & 165 & 13.95 & 12.72 \\
\hline SEm \pm & 12.18 & 12.90 & 2.20 & 2.05 & 11.14 & 11.51 & 0.81 & 0.97 \\
\hline $\mathrm{CD}(\mathrm{P}=0.05)$ & 35.35 & 37.44 & 6.40 & 5.94 & 32.34 & 33.39 & 2.39 & 2.85 \\
\hline
\end{tabular}


Table.3 Effect of continuous application of fertilizers and manure on grain and straw yield of soybean

\begin{tabular}{|l|l|c|c|}
\hline \multicolumn{1}{r}{ Treatments } & \multicolumn{2}{c|}{$\begin{array}{c}\text { Soybean yield }\left(\mathbf{k g ~ h a}^{-\mathbf{1}}\right) \\
\text { Grain }\end{array}$} \\
\hline $\mathrm{T}_{1}$ & $50 \% \mathrm{NPK}$ & 600 & 1413 \\
\hline $\mathrm{T}_{2}$ & $100 \% \mathrm{NPK}$ & 725 & 1900 \\
\hline $\mathrm{T}_{3}$ & $150 \% \mathrm{NPK}$ & 1075 & 2463 \\
\hline $\mathrm{T}_{4}$ & $100 \% \mathrm{NP}$ & 665 & 1788 \\
\hline $\mathrm{T}_{5}$ & $100 \% \mathrm{~N}$ & 538 & 1356 \\
\hline $\mathrm{T}_{6}$ & $100 \% \mathrm{NPK}+\mathrm{FYM}$ & 1113 & 2713 \\
\hline $\mathrm{T}_{7}$ & $100 \% \mathrm{NPK}-\mathrm{S}$ & 963 & 2350 \\
\hline $\mathrm{T}_{8}$ & Control & 450 & 1100 \\
\hline
\end{tabular}

Tables.4 Effect of continuous application of fertilizers and manure on protein and oil yield of soybean

\begin{tabular}{|l|l|c|c|}
\hline \multicolumn{1}{|c|}{ Treatments } & \multicolumn{2}{c|}{ Soybean yield $\left(\mathbf{k g ~ h a}^{-\mathbf{1}}\right)$} \\
\hline $\mathrm{T}_{1}$ & $50 \% \mathrm{NPK}$ & Protein & Oil \\
\hline $\mathrm{T}_{2}$ & $100 \% \mathrm{NPK}$ & 1658 & 993 \\
\hline $\mathrm{T}_{3}$ & $150 \% \mathrm{NPK}$ & 2758 & 1281 \\
\hline $\mathrm{T}_{4}$ & $100 \% \mathrm{NP}$ & 4627 & 1993 \\
\hline $\mathrm{T}_{5}$ & $100 \% \mathrm{~N}$ & 2396 & 1109 \\
\hline $\mathrm{T}_{6}$ & $100 \% \mathrm{NPK}+\mathrm{FYM}$ & 1168 & 640 \\
\hline $\mathrm{T}_{7}$ & 100\%NPK-S & 4800 & 2322 \\
\hline $\mathrm{T}_{8}$ & Control & 2671 & 1515 \\
\hline & SEm \pm & 1084 & 494 \\
\hline & CD & $\mathbf{2 9 4 . 5 1}$ & $\mathbf{1 5 5 . 5 4}$ \\
\hline
\end{tabular}

Table.5 Effect of continuous application of fertilizers and manure on protein, carbohydrate and oil content (\%) in soybean seed

\begin{tabular}{|l|l|c|c|c|}
\hline & Treatments & Protein (\%) & Oil (\%) & Carbohydrate (\%) \\
\hline $\mathrm{T}_{1}$ & $50 \% \mathrm{NPK}$ & 28.09 & 16.57 & 13.41 \\
\hline $\mathrm{T}_{2}$ & $100 \% \mathrm{NPK}$ & 38.22 & 17.59 & 18.34 \\
\hline $\mathrm{T}_{3}$ & $150 \% \mathrm{NPK}$ & 43.11 & 18.53 & 20.13 \\
\hline $\mathrm{T}_{4}$ & $100 \% \mathrm{NP}$ & 36.11 & 16.65 & 16.51 \\
\hline $\mathrm{T}_{5}$ & $100 \% \mathrm{~N}$ & 23.23 & 12.72 & 12.09 \\
\hline $\mathrm{T}_{6}$ & $100 \% \mathrm{NPK}+\mathrm{FYM}$ & 43.20 & 20.74 & 20.25 \\
\hline $\mathrm{T}_{7}$ & $100 \% \mathrm{NPK}-\mathrm{S}$ & 27.67 & 15.73 & 17.18 \\
\hline $\mathrm{T}_{8}$ Control & 23.53 & 10.95 & 11.56 \\
\hline $\mathrm{SEm} \pm$ & $\mathbf{1 . 4 1 5}$ & $\mathbf{0 . 3 1 0}$ & $\mathbf{0 . 5 7 4}$ \\
\hline $\mathrm{CD}(\mathrm{p}=\mathbf{0 . 0 5})$ & $\mathbf{4 . 1 0 7}$ & $\mathbf{0 . 9 0 0}$ & $\mathbf{1 . 6 6 6}$ \\
\hline
\end{tabular}




\section{Available phosphorus and sulphur}

The results presented in Table 4 showed that the available $\mathrm{P}$ was increased consistently with increasing in level of phosphorus; $\mathrm{P}$ content in soil increased from $22.3 \mathrm{~kg} \mathrm{ha}^{-1}$ in control to $32.9 \mathrm{~kg} \mathrm{P}_{2} \mathrm{O}_{5} \mathrm{ha}^{-1}$ with application of $40 \mathrm{~kg} \mathrm{P}_{2} \mathrm{O}_{5} \mathrm{ha}^{-1}$. Similar results were also reported by Balaguravaish et al., and Chandra Deo and Khaldelwal (2009). Application of S did not affect the available $\mathrm{P}$ significantly in the soil but it tends to increase with sulphur was increased with increasing levels of sulphur application. Phosphorus application had no effect on sulphur content of the soil. The findings are similar to Chandra Deo and Khaldelwal (2009), reported that application of $60 \mathrm{~kg} \mathrm{P}_{2} \mathrm{O}_{5}$ ha had no effect on sulphur content of the soil.

\section{Effect of $P$ and $S$ on quality parameters of soybean}

\section{Protein and Oil content}

The data presented in Table 5 revealed that increase in oil content was to the tune of $18.53 \%$ to $20.54 \%$ due to application of 40 to $80 \mathrm{~kg} \mathrm{P}$ over control, while 2.32 to $4.79 \%$ increase in oil content was due to application of 10 to $20 \mathrm{~kg} \mathrm{~S} \mathrm{ha}^{-1}$. There was improvement in quality parameters (protein content, carbohydrate and oil content) due to $\mathrm{P}$ and $\mathrm{S}$ application. The improvement of protein and oil content through $\mathrm{P}$ and $\mathrm{S}$ fertilizer form application to the soybean crop. The Chaousaria et al., (2009) recorded improvement in protein and oil content due to application of phosphorus and sulphur in soybean crop. Further, Dwivedi and Bapat (1998), Majumdar et al., (2001) and recently Kumar et al., (2009) also reported that improvement in protein and oil content due to phosphorus and sulphur application. On an average, $60 \mathrm{~kg} \mathrm{P}_{2} \mathrm{O}_{5} \mathrm{ha}^{-1}$ increased protein and oil content by 7.03 and $15.24 \%$ respectively over the control. The increase in oil content with $\mathrm{P}$ application could be due to the fact that $\mathrm{P}$ helped in synthesis of fatty acids and their esterification by accelerating biochemical reactions in glyoxalate cycle (Dwivedi and Bapat, 1998). The increase in protein and oil content due to $20 \mathrm{~kg} \mathrm{~S}^{-1}$ was 11.26 and $24.17 \%$ respectively. The increase in oil content with $\mathrm{S}$ application might be due to the fact that $S$ helped in oil synthesis by enhancing the level of thioglucosides (Dwivedi and Bapat, 1998). Soybean responded more to $S$ in increasing oil and protein content of seed, as also reported by Kumar and Singh (1981). The interaction between $\mathrm{P}$ and $\mathrm{S}$ was significant. All the $S$ levels increased both oil and protein contents significantly at every level of P. The maximum protein and oil content were recorded with a treatment combination of 80 $\mathrm{kg} \mathrm{P}_{2} \mathrm{O}_{5}$ and $40 \mathrm{~kg} \mathrm{~S} \mathrm{ha}^{-1}$.

\section{References}

Aulakh, M.S., N.S. Pasricha and A.S. Azad, 1990. Phosphorus-sulphur interrelationship for soybean on P and S deficient soil. Soil Sci., 150: 705-709

Chandra Deo and R.B. Khaldelwal, 2009. 23. Nagar, R.P., G.C. Mali and P. Lal, 1993. Effect of Effect of $\mathrm{P}$ and $\mathrm{S}$ nutrition on yield and quality of phosphorus and sulphur on yield and chemical chickpea (Cicer arietinum L.). J. Indian Soc. Soil Sci., composition of soybean in Vertisols. J. Indian Soc. 57: 352-356.

Chaurasia, Amit Kumar, G.P. Richharia and Shridha Chaurasia (2009). Response of Soybean (Glycine max) to doses and sources of sulphur. Indian J. of Agricultural Sciences, 79(5):356-358.

Choudhary, H.P. and S.K. Das, 1996. Effect of P, content of black gram (Phaseolus mungo L.) $\mathrm{S}$ and Mo application on yield of rainfed blackgram J. Indian Soc. Soil Sci., 52: 266269.

Dwivedi, A.K., and P.N. Bapat, 1998. Sulphur Phosphrous interaction on the synthesis of nitrogenous fraction and oil in soybean. 
J.Indian Soc.Soil Sci., 46:254-257

Dwivedi, A.K. and P.N. Bapat (1998). Sulphurphosphorus interaction on the synthesis of nitrogenous fractions andoil in soybean. $J$. Indian Soc. Soil Sci., 46 (2):254-257.

Hedge, D.M. and I.Y.L.N. Murthy, 2005. Management of secondary nutrients. Indian J. Fert.1: 93-100.

Henry, A., S.P.S. Choudhary and B.K. Mathur, 2008. Clusterbean (Guar). In Souvenir of the 3rd National

Indian J. Fert., 2: 37-52.

Islam, M.N., S. Hoque and A. Islam, 2006. Effect of $\mathrm{P} \quad \mathrm{x} \quad \mathrm{S}$ interactions on nutrient concentration and yield of wheat, rice and mungbean. J. Indian Soc. Soil Sci., 54: 8691.

Jogendra-Singh, P., J.C. Tarafdar and B.R. Gupta, 1997. Sulphur fertilization for increased production of summer moong (Vigna radiate L.). J. Indian Soc. Soil Sci., 45: 256-528.

Kumar Mahesh, B.K. Nad and P. Raina (2009). Effect of phosphorus and sulphur applied along with FYM and green leaf manure on their uptake and yield of mustard and soybean. J. AridLegumes., 6 (2): 96-100.

Kumar, V. and M. Singh, 1980. Sulphur, phosphorus and molybdenum interaction in relationship to growth, uptake and utilization of sulphur in soybean. Soil Sci., 128: 297-304.

Kumawat, B.L., A.R.K. Pathan and R. Chahan, 2004. Response of taramirra to sulphur and phosphorus application on Typic Pasmmnt. J. Indian Soc. Soil Sci., 52: 476-478.

Majumdar, B., M.S. Venkatesh, B. Lal and Kailash Kumar (2001). Response of soybean (Glycine max) to phosphorus and sulphur in acid alfisol of Meghalaya. Indian Journal of Agronomy, 46 (3): 500-505.
Marok, A.S. and G. Dev, 1980. Phosphorus and sulphur inter-relationship in wheat. J. Indian Soc. Soil Sci., 28: 184-186.

Nagar, R.P., G.C. Mali and P. Lal, 1993. Effect of phosphorus and sulphur on yield and chemical composition of soybean in Vertisols. J. Indian Soc. Soil Sci., 41: 385386.

Pandey, I.P. O.M. Sharan and S.B. Pandey, 2003. Response of linseed to different levels of phosphorus and sulphur application. Ann. Plant SoilRes., 5: 99-101.

Randhawa, P.S. and C.L. Arora, 2000. Phosphorus-sulphur interaction effects on dry matter yield and nutrition uptake by wheat. J. Indian Soc. Soil Sci., 48: 536-540.

Shankaralingappa, B.C., B. Shivaraj, K.P. Krishnappa and A.P. Nagaraja, 1999. Phosphorus-sulphur interaction effect on growth and yield of cowpea. Karnataka J. Agric. Sci., 12: 15-19.

Singh, V., V. Kumar and S.P.S. Karawasra, 1995. Interaction of sulphur and zinc on dry matter yield, concentration and uptake of sulphur in green gram (Vigna radiata L.). Crop Res., 9: 32-41.

Sinha, R.B., R. Sakal and S. Kumar, 1995. Sulphur and phosphorus nutrition of winter maize in calcareous soil. J. Indian Soc. Soil Sci., 43: 413-418.

Symposium on Enhancing Productivity, Nutritional Security and Export Potential through Arid Legumes held at CAZRI, Jodhpur, 28-30 June, 2008, pp: 53.

Teotia, U.S., V.S. Mehta, D. Ghosh and P.C. Srivastava, 2000. Phosphorus-Sulphur interaction in moongbean (Vigna radiata $\mathrm{L}$. Wilczek): I. Yield, phosphorus and sulphur contents. Legume Res., 23: 106-109.

Tiwari, K.N. and B.R. Gupta, 2006. Sulphur for sustainable high yield agriculture in Uttar Pradesh.

\section{How to cite this article:}

Jarupula Suman, B.S. Dwivedi, A.K. Dwivedi and Pandey, S.K. 2018. Interaction Effect of Phosphorus and Sulphur on Yield and Quality of Soybean in a Vertisol. Int.J.Curr.Microbiol.App.Sci. 7(03): 152-158. doi: https://doi.org/10.20546/ijcmas.2018.703.018 